Supporting information

for

\title{
Benzothiazole amphiphiles ameliorate Amyloid $\beta$-related cell toxicity and oxidative stress
}

\author{
Jessica L. Cifelli, ${ }^{\dagger}$ Tim S. Chung, ${ }^{\dagger}$ Haiyan Liu, ${ }^{\dagger}$ Panchika Prangkio, ${ }^{\dagger}$ Michael Mayer ${ }^{\dagger}$ and \\ Jerry Yang * *
}

'University of California, San Diego, Department of Chemistry and Biochemistry, 9500 Gilman Drive, La Jolla, CA 92093-0358; 'Department of Biomedical Engineering, University of Michigan, 1101 Beal Avenue, Ann Arbor, MI 48109

*CORRESPONDING AUTHOR EMAIL ADDRESS jerryyang@ucsd.edu Jerry Yang: Tel: 858-534-6006; Fax: 858-534-4554 


\section{Chemical Synthesis of BAMs1-3:}
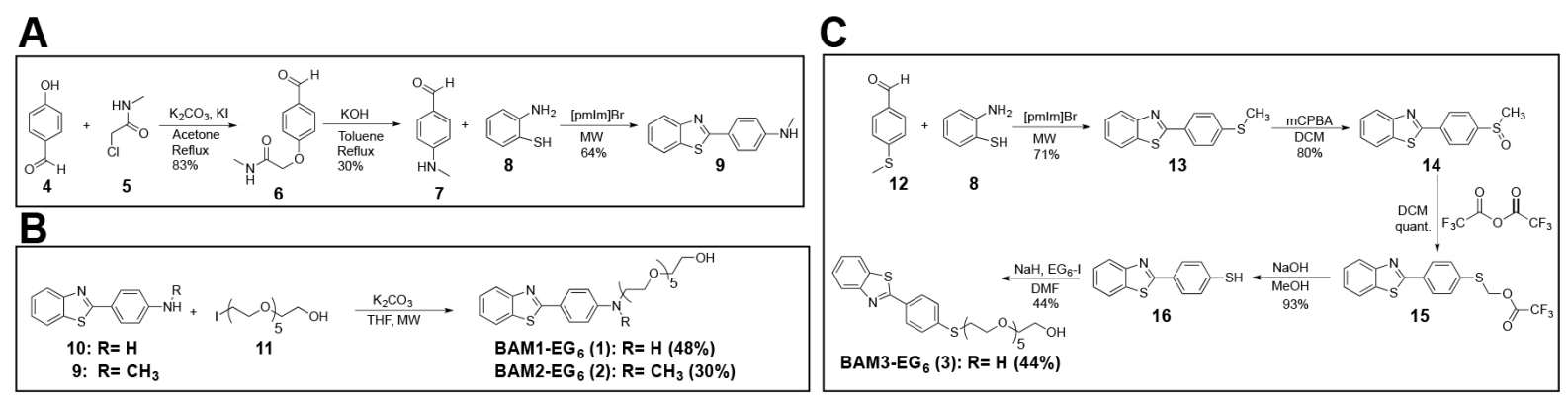

Scheme S1. Synthetic scheme for the preparation of BAM1-3.

We prepared compounds 1-3 as recently reported. ${ }^{1}$ However, to facilitate accessibility to this information, we also include the details of the syntheses here:

\section{Alkylation of 4-hydroxy benzaldehyde (6):}

4-Hydroxy benzaldehyde 4 (2g, 16.5 mmole, 1.1 equiv.) and anhydrous potassium carbonate $\left(\mathrm{K}_{2} \mathrm{CO}_{3}\right)(4.14 \mathrm{~g}, 29.9$ mmole, 2 equiv.) were dissolved in acetone $(30 \mathrm{~mL})$ and let stir under nitrogen $\left(\mathrm{N}_{2}\right)$ for 30 min. Then 2-chloro-N-methylacetamide 5 (1.61g, 15 mmole, 1 equiv.) and potassium iodide (KI) (249 mg, 1.5 mmole, 0.1 equiv.) were added and let reflux for $24 \mathrm{~h}$. After cooling to room temperature (RT), solids were filtered off and the solvent was removed and replaced with dichloromethane (DCM). Extraction was done with 10\% sodium hydroxide $(\mathrm{NaOH})$ followed by column chromatography purification $(95 \% \mathrm{DCM} /$ methanol $(\mathrm{MeOH}))$ to yield compound 6 as a white solid $(2.4 \mathrm{~g}, 83 \%$ yield $)$

${ }^{1} \mathrm{HNMR}\left(500 \mathrm{MHz}, \mathrm{CDCl}_{3}\right): \delta 9.91(\mathrm{~s}, 1 \mathrm{H}), 7.88(\mathrm{~d}, 2 \mathrm{H}), 7.04(\mathrm{~d}, 2 \mathrm{H}), 6.50(\mathrm{~b}, 1 \mathrm{H}), 4.57(\mathrm{~s}$, 2H), 2.93 (s, 3 H). ESI-MS $(m / z): 194.12[\mathrm{M}+\mathrm{H}]^{+}$

\section{Synthesis of 4-N-(methylamino) benzaldehyde (7):}


To a round bottom with dry toluene, compound 6 (300 mg, 1.55 mmole, 1 equiv.) and potassium hydroxide $(\mathrm{KOH})$ pellets $(174 \mathrm{mg}, 3.10$ mmole, 2 equiv.) were added and let reflux for $24 \mathrm{~h}$. After cooling to RT, the reaction was put on ice and water was added. The organic layer was washed $3 \mathrm{x}$ with water, dried, and concentrated. Column chromatography (50\% ethyl acetate (EtOAc)/Hexanes) yielded compound 7 as a red solid (64 mg, 30\% yield).

${ }^{1} \mathrm{H}$ NMR $\left(500 \mathrm{MHz}, \mathrm{CDCl}_{3}\right): \delta 9.72(\mathrm{~s}, 1 \mathrm{H}), 7.71(\mathrm{~d}, 2 \mathrm{H}), 6.61(\mathrm{~d}, 2 \mathrm{H}), 4.41(\mathrm{~b}, 1 \mathrm{H}), 2.91(\mathrm{~s}, 3$ H). ESI-MS $(m / z): 136.19[\mathrm{M}+\mathrm{H}]^{+}$

\section{Synthesis of Benzothiazole (9) ${ }^{2}$ :}

A microwave vial was charged with 2-aminothiophenol 7 (45 mg, 0.36 mmole. 1 equiv.), followed by 1-pentyl-3-methylimidazolium bromide ([pmIm] $] \mathrm{Br})^{3}(29 \mathrm{mg}, 0.18 \mathrm{mmole}, 0.5$ equiv.) and then 4-(methylamino)benzaldehyde 8 ( $49 \mathrm{mg}, 0.36$ mmole, 1 equiv.). The mixture was irradiated under $\mathrm{MW}$ conditions $\left(150^{\circ} \mathrm{C}, 4 \mathrm{~min}\right)$. The reaction mixture was extracted with ether $/ \mathrm{H}_{2} \mathrm{O}(4 \mathrm{x})$. The ether was evaporated and the compound was purified by column chromatography $(25 \% \mathrm{DCM} / 70 \%$ Hexanes $/ 5 \%$ EtOAc), affording compound $\mathbf{9}$ as a light orange solid (55 mg, 64\% yield).

${ }^{1} \mathrm{H}$ NMR (500 MHz, $\left.\mathrm{CDCl}_{3}\right): \delta 8.02(\mathrm{~d}, 1 \mathrm{H}), 7.96(\mathrm{~d}, 2 \mathrm{H}), 7.84(\mathrm{~d}, 1 \mathrm{H}), 7.44(\mathrm{t}, 1 \mathrm{H}), 7.32(\mathrm{t}, 1$ H), $6.66(\mathrm{~d}, 2 \mathrm{H}), 2.92(\mathrm{~s}, 3 \mathrm{H}) .{ }^{13} \mathrm{C} \mathrm{NMR}\left(400 \mathrm{MHz}, \mathrm{CDCl}_{3}\right): \delta 169.05,154.53,151.82$, 134.73, $129.32(2 \mathrm{C}), 126.25,124.50,122.68,122.53,121.60,112.24$ (2C), 30.54. ESI-MS $(\mathrm{m} / \mathrm{z}): 241.0[\mathrm{M}+\mathrm{H}]^{+}$

\section{General protocol for (ethylene glycol $)_{6}\left(\mathbf{E G}_{6}\right)$ addition:}


Synthesis of 17-iodo-3,6,9,12,15-pentaoxaheptadecan-1-ol (EG 6 -I) was prepared as previously described ${ }^{4}$. A microwave vial was charged with $\mathrm{EG}_{6}-\mathrm{I}$ (1 equiv.), benzothiazole aniline $\mathbf{9}$ or $\mathbf{1 0}$ ( 2 equiv.), potassium carbonate ( 3 equiv.) and tetrahydrofuran (THF). The mixture was irradiated under MW $\left(125^{\circ} \mathrm{C}, 2 \mathrm{~h}\right)$. The mixture was filtered, concentrated and normal phase column chromatography (4\% $\mathrm{MeOH} /$ EtOAc $)$ followed by reverse phase column chromatography $\left(3: 1 \mathrm{MeOH} / \mathrm{H}_{2} \mathrm{O}\right)$ yielded compound $\mathbf{1}(285 \mathrm{mg}, 48 \%$ yield) or compound 2 (13 mg, 30\% yield).

\section{BAM1-EG $_{6}(1)$ :}

${ }^{1} \mathrm{H}$ NMR $\left(500 \mathrm{MHz}, \mathrm{CDCl}_{3}\right): \delta 7.99(\mathrm{~d}, 1 \mathrm{H}), 7.92(\mathrm{~d}, 2 \mathrm{H}), 7.84(\mathrm{~d}, 1 \mathrm{H}), 7.43(\mathrm{t}, 1 \mathrm{H}), 7.30(\mathrm{t}$, $1 \mathrm{H}), 6.76(\mathrm{~d}, 2 \mathrm{H}), 4.97(\mathrm{~b}, 1 \mathrm{H}), 3.73-3.58(\mathrm{~m}, 22 \mathrm{H}), 3.39(\mathrm{t}, 2 \mathrm{H}) .{ }^{13} \mathrm{C} \mathrm{NMR}(500 \mathrm{MHz}$, $\left.\mathrm{CDCl}_{3}\right): \delta 168.92,154.51,151.38,134.74,129.13(2 \mathrm{C}), 126.24,124.54,123.20 .122 .55$, $121.60,113.28(2 \mathrm{C}), 71.68,69.81-69.03(69.81,69.59,69.45,69.30,69.24,69.23,69.03)$, 68.74, 60.44, 43.86. HR/MS (ESI +): Calcd for $\left[\mathrm{C}_{25} \mathrm{H}_{34} \mathrm{~N}_{2} \mathrm{O}_{6} \mathrm{~S}+\mathrm{Na}\right] 513.2030$ found 513.2029 $[\mathrm{M}+\mathrm{Na}]^{+}$

\section{BAM2-EG $_{6}$ (2):}

${ }^{1} \mathrm{HNMR}\left(500 \mathrm{MHz}, \mathrm{CDCl}_{3}\right): \delta 7.96(\mathrm{~d}, 1 \mathrm{H}), 7.93(\mathrm{~d}, 2 \mathrm{H}), 7.84(\mathrm{~d}, 1 \mathrm{H}), 7.42(\mathrm{t}, 1 \mathrm{H}), 7.29(\mathrm{t}$, $1 \mathrm{H}), 6.76(\mathrm{~d}, 2 \mathrm{H}), 3.72-3.28(\mathrm{~m}, 24 \mathrm{H}), 3.07(\mathrm{~s}, 3 \mathrm{H}) .{ }^{13} \mathrm{C} \mathrm{NMR}\left(500 \mathrm{MHz}, \mathrm{CDCl}_{3}\right): \delta 168.94$, $154.64,151.39,134.74,129.17(2 \mathrm{C}), 126.19,124.40,122.49,121.57,121.55,111.80(2 \mathrm{C})$ 72.76, 71.0-70.50 (71.00, 70.88, 70.85, 70.80, 70.76, 70.75, 70.71, 70.50), 68.73, 61.93, 52.29, 39.26. HR/MS (ESI-TOFMS +): Calcd for $\left[\mathrm{C}_{26} \mathrm{H}_{36} \mathrm{~N}_{2} \mathrm{O}_{6} \mathrm{~S}+\mathrm{Na}\right] 527.2191$ found 527.2187 $[\mathrm{M}+\mathrm{Na}]^{+}$ 


\section{2-(4-(methylthio)phenyl)benzo[d]thiazole (13):}

2-amino thiophenol 8 (376mg, 3 mmol, 1 equiv.), [pmIm]Br (400 mg, 0.5 equiv), 4(methylthio)benzaldehyde 12 (457 mg, $3 \mathrm{mmol}, 1$ equiv.) were added respectively, into a 5 $\mathrm{mL}$ microwave tube with a stir bar. The reaction tube was microwaved for $4 \mathrm{~min}$ at $130^{\circ} \mathrm{C}$. The reaction mixture was dissolved in diethyl ether and extracted with water to remove the ionic liquid solution. The diethyl ether was removed under reduced pressure and the crude solid 13 was purified by recrystallization in a 3:1 mixture of hexanes:EtOAc (547 mg, 71\% yield). Spectra matched previously reported sample..$^{5}$

${ }^{1} \mathrm{H}$ NMR $\left(400 \mathrm{MHz}, \mathrm{CDCl}_{3}\right): \delta 8.05(\mathrm{~d}, 1 \mathrm{H}), 8.01(\mathrm{~d}, 2 \mathrm{H}), 7.90(\mathrm{~d}, 1 \mathrm{H}), 7.49(\mathrm{t}, 1 \mathrm{H}), 7.38(\mathrm{t}$, 1H), $7.33(\mathrm{~d}, 2 \mathrm{H}), 2.55(\mathrm{~s}, 3 \mathrm{H})$. ESI-MS (m/z): $258.25[\mathrm{M}+\mathrm{H}]^{+}$

\section{2-(4-(methylsulfinyl)phenyl)benzo[d]thiazole (14):}

2-(4-(methylthio)phenyl)benzo[d]thiazole $13(300 \mathrm{mg}, 1.1 \mathrm{mmol})$ was dissolved in $6 \mathrm{~mL}$ of DCM. meta-chloroperoxybenzoic acid (m-CPBA) (242 mg, $1.4 \mathrm{mmol})$ was dissolved in $4 \mathrm{~mL}$ of DCM and added dropwise at $0{ }^{\circ} \mathrm{C}$ to the methyl sulfide 13 solution over a period of $20 \mathrm{~min}$. $\mathrm{NaHCO}_{3}(80 \mathrm{mg})$ was added and the solution was let stir. The reaction mixture was monitored by TLC analysis (100\% EtOAc) until completion. The white precipitate was filtered away and the DCM was removed under reduced pressure to afford a white solid. The solid was purified by recrystallization in 100\% EtOAc to give product 14 (254 mg, 80\% yield).

${ }^{1} \mathrm{H}$ NMR $\left(400 \mathrm{MHz}, \mathrm{CDCl}_{3}\right): \delta 8.26(\mathrm{~d}, 2 \mathrm{H}), 8.11(\mathrm{~d}, 1 \mathrm{H}), 7.94(\mathrm{~d}, 1 \mathrm{H}), 7.78(\mathrm{~d}, 2 \mathrm{H}), 7.53(\mathrm{t}$, 1H), $7.44(\mathrm{t}, 1 \mathrm{H}), 2.79(\mathrm{~s}, 3 \mathrm{H})$. ESI-MS $(\mathrm{m} / \mathrm{z}): 274.17[\mathrm{M}+\mathrm{H}]^{+}, 296.10[\mathrm{M}+\mathrm{Na}]^{+}$ 


\section{((4-(benzo[d]thiazol-2-yl)phenyl)thio)methyl 2,2,2-trifluoroacetate (15):}

2-(4-(methylsulfinyl)phenyl)benzo[d]thiazole (14) $(50 \mathrm{mg}, 0.18 \mathrm{mmol})$ was dissolved in $2 \mathrm{~mL}$ of freshly distilled DCM in an oven dried $50 \mathrm{~mL}$ round bottom. Trifluoroacetic anhydride (TFAA) $(0.15 \mathrm{~mL})$ was added to the reaction flask and the reaction was gently refluxed at 40 ${ }^{\circ} \mathrm{C}$ for $2 \mathrm{~h}$ under $\mathrm{N}_{2}$. The solvent was removed under reduced pressure to afford the crude product 15 (72 $\mathrm{mg}$, approximately quantitative conversion). The product was taken on to the next step without further purification.

${ }^{1} \mathrm{H}$ NMR $\left(500 \mathrm{MHz}, \mathrm{CDCl}_{3}\right): \delta 8.07(\mathrm{~m}, 3 \mathrm{H}), 7.92(\mathrm{~d}, 1 \mathrm{H}), 7.58(\mathrm{~d}, 8 \mathrm{~Hz}, 2 \mathrm{H}), 7.53(\mathrm{t}, 1 \mathrm{H})$, $7.43(\mathrm{t}, 1 \mathrm{H}), 5.70(\mathrm{~s}, 2 \mathrm{H})$

\section{4-(benzo[d]thiazol-2-yl)benzenethiol (16):}

((4-(benzo[d]thiazol-2-yl)phenyl)thio)methyl 2,2,2-trifluoroacetate (15) (72mg, $0.19 \mathrm{mmol})$ was dissolved in $3 \mathrm{~mL}$ of $\mathrm{MeOH}$ and $0.6 \mathrm{~mL}$ of $1 \mathrm{M} \mathrm{NaOH}$ was added to the reaction flask and refluxed under $\mathrm{N}_{2}$ for $1 \mathrm{~h}$. The reaction mixture was cooled and the solvent was removed under reduced pressure. $0.6 \mathrm{~mL}$ of $1 \mathrm{M} \mathrm{HCl}$ was then added to the crude mixture and the product was extracted into EtOAc by washing the aqueous layer with $3 \times 2 \mathrm{~mL}$ of EtOAc. The organic layer was washed with a saturated $\mathrm{NaCl}$ solution and dried over $\mathrm{Na}_{2} \mathrm{SO}_{4}$. The EtOAc was removed under reduced pressure to afford the crude product 16 (44 mg, 93\% crude yield). ${ }^{1} \mathrm{H}$ NMR $\left(500 \mathrm{MHz}, \mathrm{CDCl}_{3}\right): \delta 8.08(\mathrm{~d}, 1 \mathrm{H}), 7.95(\mathrm{~d}, 2 \mathrm{H}), 7.90(\mathrm{~d}, 1 \mathrm{H}), 7.51(\mathrm{t}, 1 \mathrm{H}), 7.39$ (m, 3H), $3.68(\mathrm{~s}, 1 \mathrm{H})$. ESI-MS $(\mathrm{m} / \mathrm{z}): 244.28[\mathrm{M}+\mathrm{H}]^{+}$ 
In an oven dried $50 \mathrm{~mL}$ round bottom, solid sodium hydride $(\mathrm{NaH})(2 \mathrm{mg}, 0.074 \mathrm{mmol})$ was added and the round bottom was tightly capped with a rubber septum. The round bottom was purged with $\mathrm{N}_{2}$. The crude 4-(benzo[d]thiazol-2-yl)benzenethiol (16) (12mg, $0.05 \mathrm{mmol}, 1$ equiv.) was dissolved in $1 \mathrm{~mL}$ of freshly distilled dimethylformamide (DMF) and added dropwise to the round bottom flask containing $\mathrm{NaH}$. The reaction mixture was stirred for 30 min. 17-iodo-3,6,9,12,15-pentaoxaheptadecan-1-ol (EG-I, $20 \mathrm{mg}, 0.05 \mathrm{mmol}, 1$ equiv.) was dissolved in $1 \mathrm{~mL}$ of freshly distilled DMF in a separate vial and added dropwise into reaction mixture. The reaction was then refluxed under $\mathrm{N}_{2}$ for $12 \mathrm{~h}$. The reaction mixture was cooled to RT and the solvent was removed under reduced pressure. The product was purified via silica gel flash chromatography (using a gradient of EtOAc:MeOH 0-4\%) to afford the desired product 3 as a yellow oil $\left(\mathrm{R}_{\mathrm{f}}=0.24,100 \%\right.$ EtOAc). The yellow oil product was purified once more using a reverse-phase preparatory plate (using a 3:1 mixture of $\mathrm{MeOH}: \mathrm{H}_{2} \mathrm{O}$ as eluent) to give final product 3 ( $11 \mathrm{mg}, 44 \%$ yield).

\section{BAM3-EG $_{6}$ (3):}

${ }^{1} \mathrm{H}$ NMR $\left(500 \mathrm{MHz}, \mathrm{CDCl}_{3}\right): \delta 8.04(\mathrm{~d}, 1 \mathrm{H}), 7.99(\mathrm{~d}, 2 \mathrm{H}), 7.89(\mathrm{~d}, 1 \mathrm{H}), 7.48(\mathrm{t}, 1 \mathrm{H}), 7.41(\mathrm{~d}$, $2 \mathrm{H}), 7.37(\mathrm{t}, 1 \mathrm{H}), 3.74-3.70(\mathrm{~m}, 4 \mathrm{H}), 3.64(\mathrm{~m}, 16 \mathrm{H}), 3.60-3.58(\mathrm{~m}, 2 \mathrm{H}), 3.20,(\mathrm{t}, 2 \mathrm{H}) .{ }^{13} \mathrm{C} N M R$ $\left(500 \mathrm{MHz}, \mathrm{CDCl}_{3}\right): \delta 167.42,154.09,140.57,134.88,130.83,128.01,127.86,126.38$, $125.18,123.08,121.62,72.50,70.64-70.30(70.64,70.59,70.55,70.53,70.50,70.30), 69.68$, 61.74, 32.08. HR/MS: calcd for $\mathrm{C}_{25} \mathrm{H}_{33} \mathrm{NO}_{6} \mathrm{~S}_{2}[\mathrm{M}+\mathrm{Na}] 530.1641$ found $[\mathrm{M}+\mathrm{Na}] 530.1640$ 
Single Ion Channel Recordings for BAMs. The single-channel conductances of pores formed

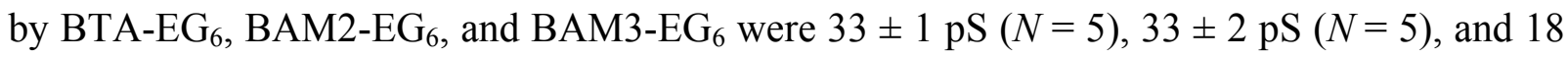
$\pm 2 \mathrm{pS}(N=3)$, respectively, whereas the single-channel conductance of pores formed by BAM1-EG 6 was broadly distributed with a median value of $32 \mathrm{pS}$. All recordings were performed in $1 \mathrm{M} \mathrm{CsCl}$ and $10 \mathrm{mM}$ HEPES buffer $(\mathrm{pH}=7.4)$ using DiPhyPC lipids.

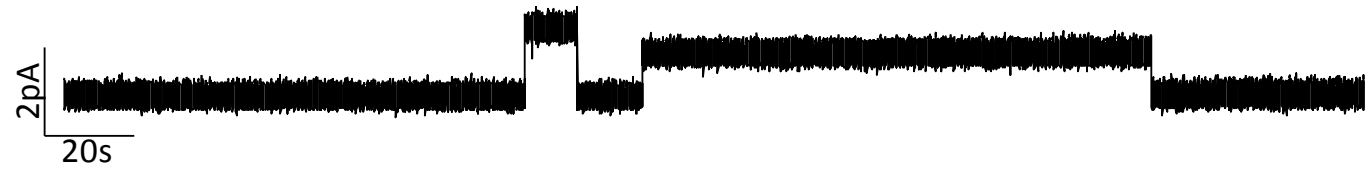

Figure S1. Current versus time trace from single channel recordings of BAM1-EG $6(150 \mu \mathrm{M}$ at $+50 \mathrm{mV})$.

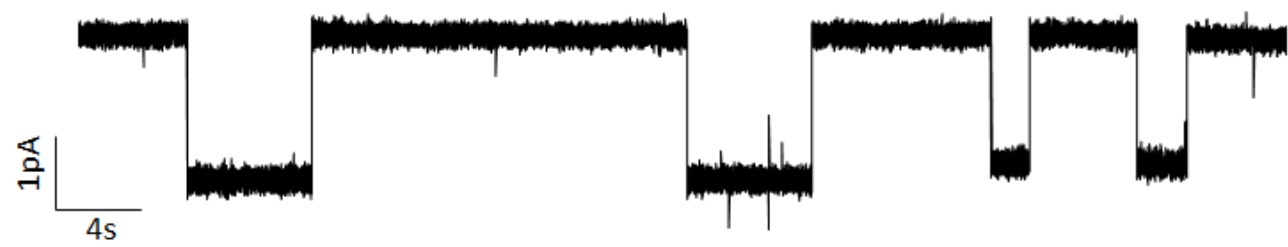

Figure S2. Current versus time trace from single channel recordings of BAM2-EG $6(40 \mu \mathrm{M}$ at $-50 \mathrm{mV})$.

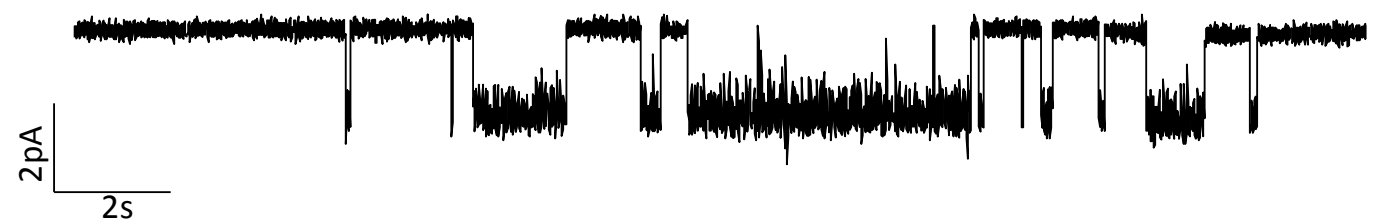

Figure S3 . Current versus time trace from single channel recordings of BAM3-EG 6 (50 $\mu \mathrm{M}$ at $-100 \mathrm{mV})$. 
Cytotoxicity Curves for BTA-EG 6 and BAM1-3 In Differentiated SH-SY5Y Cells.

A

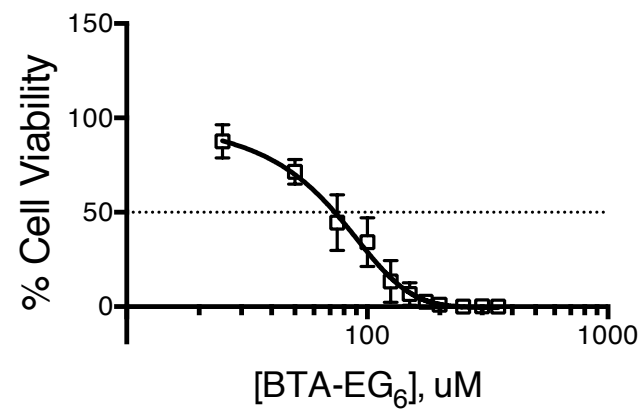

C

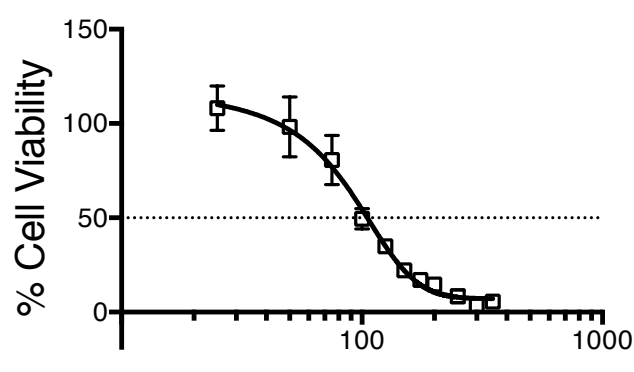

[Compound 2], uM

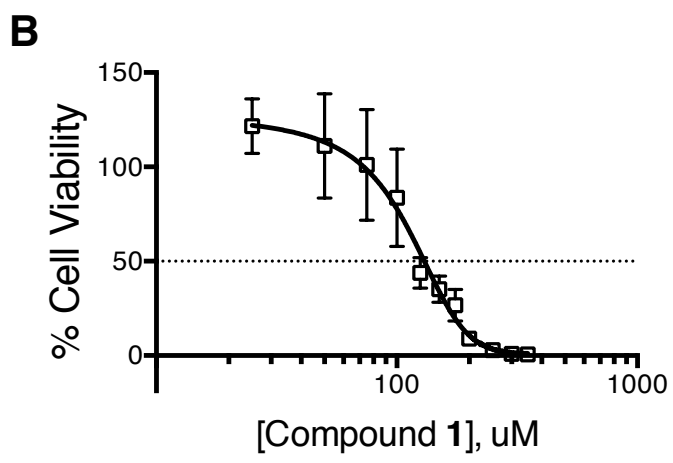

D

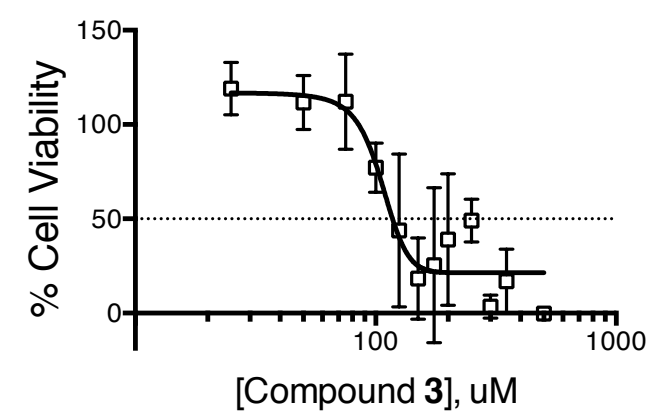

Figure S4. Toxicity curves for A) BTA-EG 6 , (B) Compound 1, (C) Compound 2 and (D) Compound $\mathbf{3}$ in differentiated SH-SY5Y neuroblastoma cells. 
Preparation of Aggregated A $\mathbf{\beta}(\mathbf{1 - 4 2})$. Aggregated $A \beta(1-42)$ was prepared as previously described. $^{6}$ Briefly, $A \beta(1-42)$ was initially solubilized in $100 \%$ 1,1,1,3,3,3,-hexafluoro-2propanal(HFIP) to $1 \mathrm{mM}$ concentration at $\mathrm{RT}$ for $21 \mathrm{~h}$ with shaking. The solution was sonicated and vortexed before it was diluted in cold nanopure water $\left(2: 1 \mathrm{H}_{2} \mathrm{O}: \mathrm{HFIP}\right)$. Aliquoted fractions were lyophilized for 2 days, followed by storage at $-80{ }^{\circ} \mathrm{C}$ until use. Solutions of $\mathrm{A} \beta$ were obtained by dissolving $\mathrm{A} \beta$ in sterile PBS to a concentration of $100 \mu \mathrm{M}$ and incubated at $37^{\circ} \mathrm{C}$ for 3 days before use. Western blot analysis of the three-day incubated $\mathrm{A} \beta$ was carried out to determine composition. Briefly, proteins were separated using a $12 \%$ Tris-Bis gel $\left(\mathrm{NuPAGE}^{\circledR}\right.$ Novex $^{\circledR}$ ) followed by transfer to nitrocellulose membrane (Novex ${ }^{\circledR}$, LC2000) (1h, RT). Membranes were blocked with 5\% Milk/TBST (45 min, RT, with shaking) and then incubated with a mouse monoclonal antibody (6E10) overnight $\left(4{ }^{\circ} \mathrm{C}\right.$, with shaking). Following primary antibody incubation, membranes were washed with TBST ( 3 x 10 min), and then incubated with an ECL ${ }^{\mathrm{TM}}$ Horseradish Peroxidase linked Anti-mouse secondary (GE, \#NA931V). After washing the membrane (6 x $5 \mathrm{~min} / \mathrm{TBST})$ the detection of monomeric, oligomeric, and fibrillary $\mathrm{A} \beta$ was carried out using an Amersham ${ }^{\mathrm{TM}}$ ECL $^{\mathrm{TM}}$ Prime Western Blotting Detection Reagent (GE Healthcare) followed by detection on film (Freedom Imaging, SRX-101A). The gel was quantified using FIJI and percentage of each composition was calculated by dividing the intensity of each aggregation state over the total intensity for $A \beta$ in the lane. This data showed that this preparation of $\mathrm{A} \beta$ lead to a composition of $\sim 12 \%$ low $\mathrm{MW}$ oligomers/monomers, $\sim 16 \%$ medium-sized MW oligomers, and $\sim 72 \%$ mixture of soluble protofibrils/fibrils (Figure S5). Aggregated A $\beta$ was also characterized by EM, MALDI-TOF, and Thioflavin $\mathrm{T}$ (data not shown). 


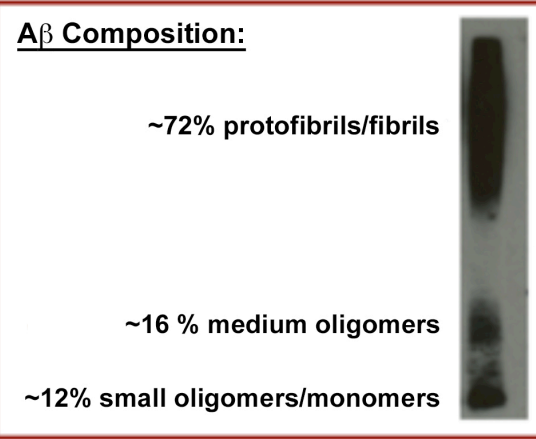

Figure S5. Western blot detection of the composition of $A \beta(1-42)$ aggregation states. 
Binding Curves for BTA-EG 6 and BAMs to Aggregated Aß (1-42).
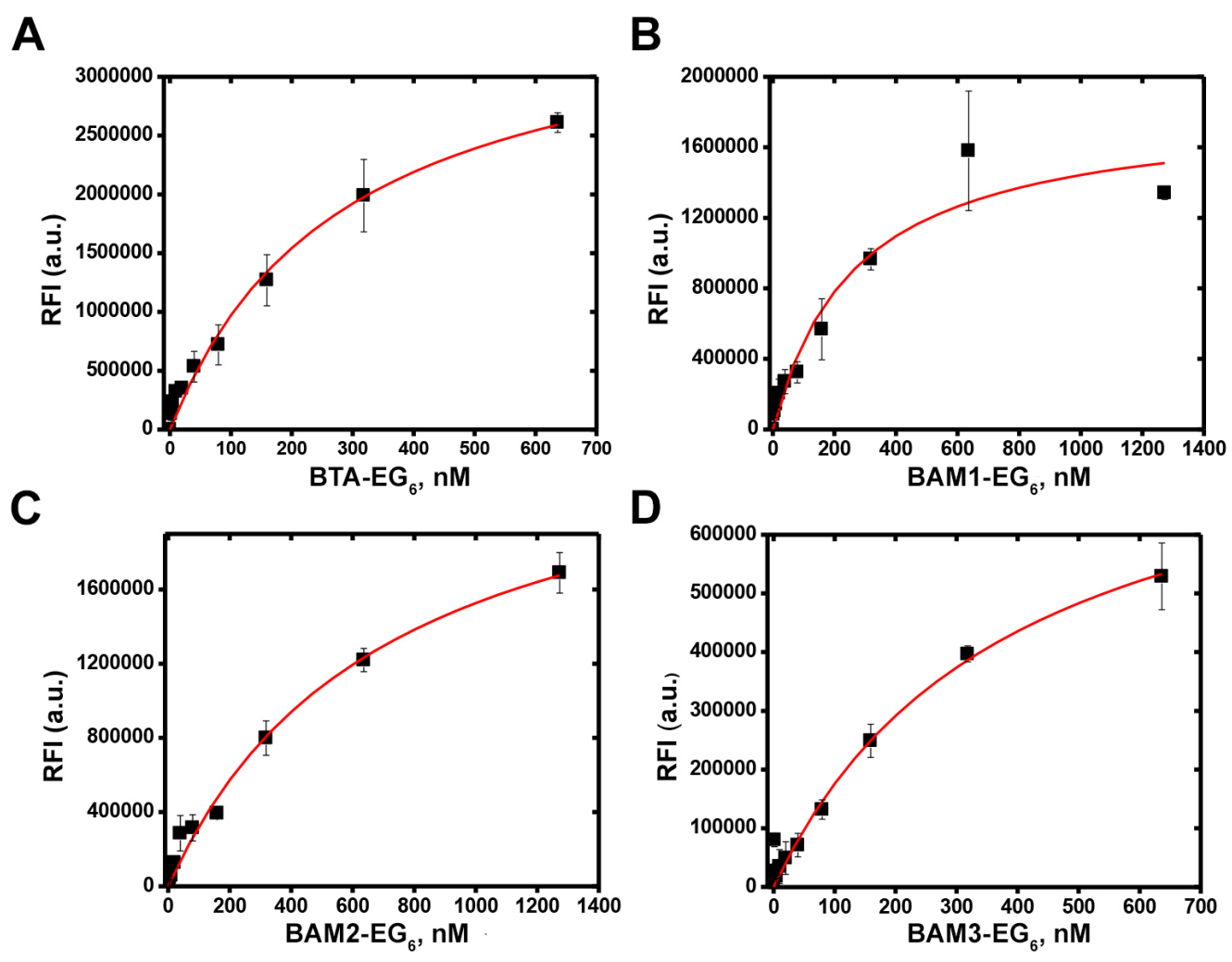

Figure S6. Plot of the fluorescence intensity binding curve of (A) BTA-EG $6(\lambda=420 \mathrm{~nm})$, (B) BAM1-EG $_{6}(\lambda=420 \mathrm{~nm}),(\mathrm{C}) \mathrm{BAM} 2-\mathrm{EG}_{6}(\lambda=428 \mathrm{~nm})$ and $(\mathrm{D}) \mathrm{BAM} 3-\mathrm{EG}_{6}(\lambda=398 \mathrm{~nm})$ with aggregated $A \beta(1-42)$. 
Mass Spectrometry Analysis of BAMs For Anti-Oxidant Properties. In order to verify that the newly synthesized BAMs did not exhibit inherent anti-oxidant effects mass spectrometry (MS) was performed and compared for compounds in water or in a hydrogen peroxide $\left(\mathrm{H}_{2} \mathrm{O}_{2}\right)$ solution. Here, $100 \mathrm{uM}$ solutions of BAMs1-3 was prepared in either DI water, or in $3 \mathrm{mM}$ $\mathrm{H}_{2} \mathrm{O}_{2}$ and let incubate for $24 \mathrm{~h}$. Following incubation, solutions were analyzed by MS for the presence of oxidized products. All solutions of BAMs1-3 in the presence of $\mathrm{H}_{2} \mathrm{O}_{2}$ did not show the presence of any oxidized products, indicating that these molecules were not inherently chemical anti-oxidants.

\section{BAM1 (Exact Mass: 490.21):}

In water: ESI-MS $(m / z): 491.27[\mathrm{M}+\mathrm{H}]^{+}, 513.22[\mathrm{M}+\mathrm{Na}]^{+}$

In $\mathrm{H}_{2} \mathrm{O}_{2}$ : ESI-MS $(m / z): 491.27[\mathrm{M}+\mathrm{H}]^{+}, 513.20[\mathrm{M}+\mathrm{Na}]^{+}$

BAM2 (Exact Mass: 504.23):

In water: $\operatorname{ESI-MS~}(\mathrm{m} / \mathrm{z}): 505.25[\mathrm{M}+\mathrm{H}]^{+}, 527.22[\mathrm{M}+\mathrm{Na}]^{+}$

In $\mathrm{H}_{2} \mathrm{O}_{2}$ : ESI-MS $(m / z): 505.25[\mathrm{M}+\mathrm{H}]^{+}, 527.24[\mathrm{M}+\mathrm{Na}]^{+}$

BAM3 (Exact Mass: 507.17):

In water: ESI-MS $(\mathrm{m} / z): 508.20[\mathrm{M}+\mathrm{H}]^{+}, 530.23[\mathrm{M}+\mathrm{Na}]^{+}$

In $\mathrm{H}_{2} \mathrm{O}_{2}$ : ESI-MS $(m / z): 508.16[\mathrm{M}+\mathrm{H}]^{+}, 530.24[\mathrm{M}+\mathrm{Na}]^{+}$ 


\section{ESI-MS BAM1-EG 6 in Water:}

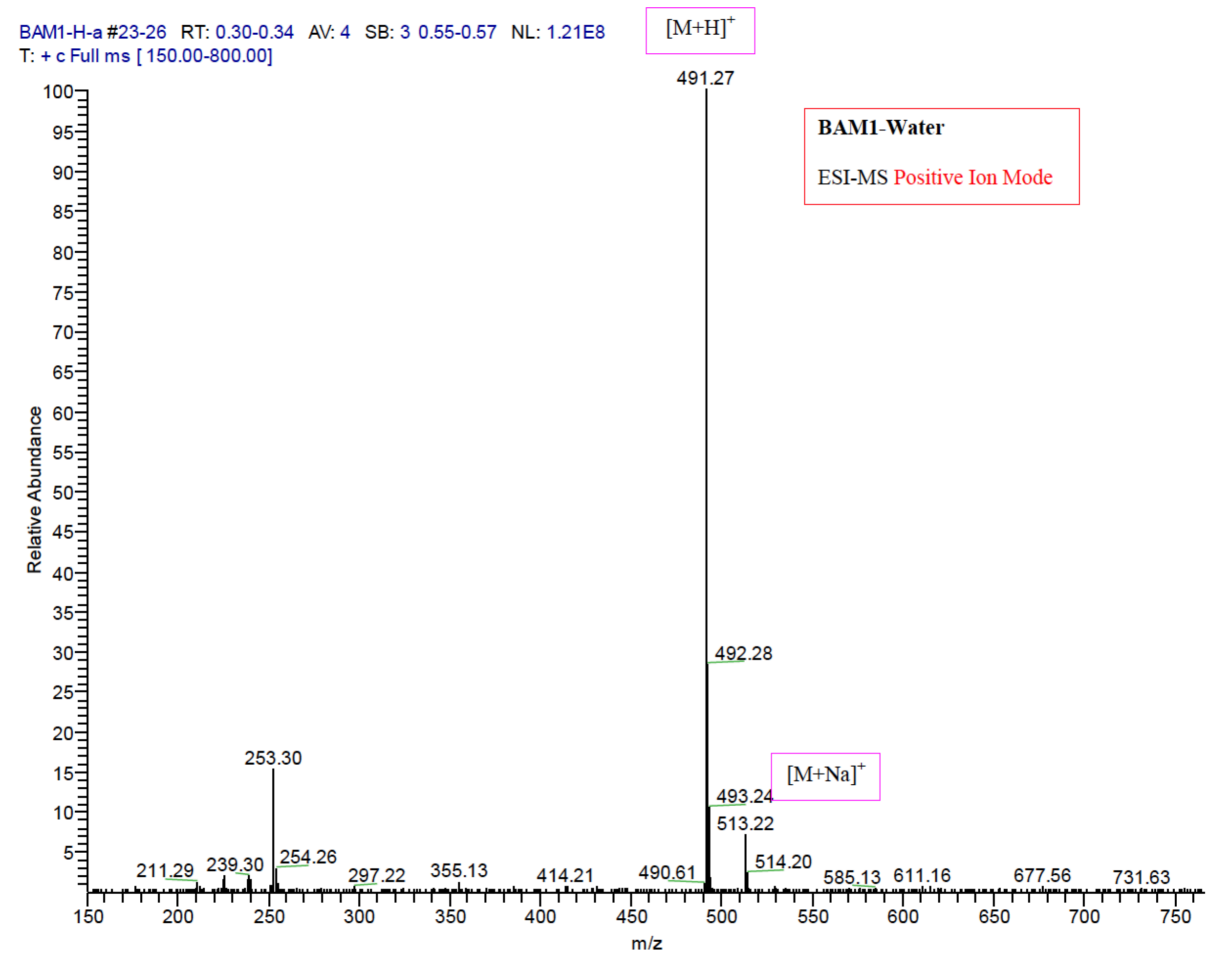

\section{ESI-MS BAM1-EG 6 after incubation for 24 hours in $3 \mathrm{mM} \mathrm{H}_{2} \mathrm{O}_{2}$ :}

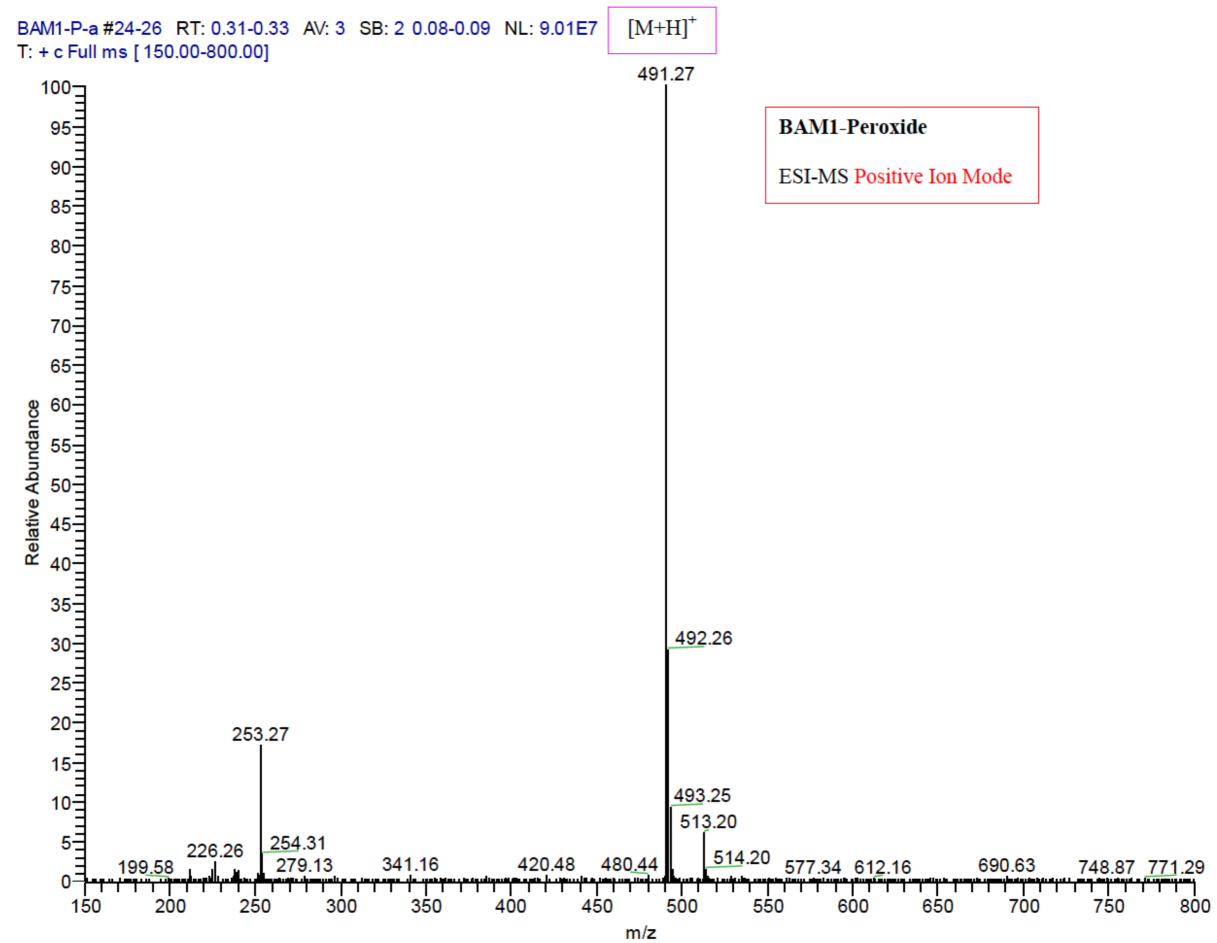




\section{ESI-MS BAM2-EG 6 in Water:}

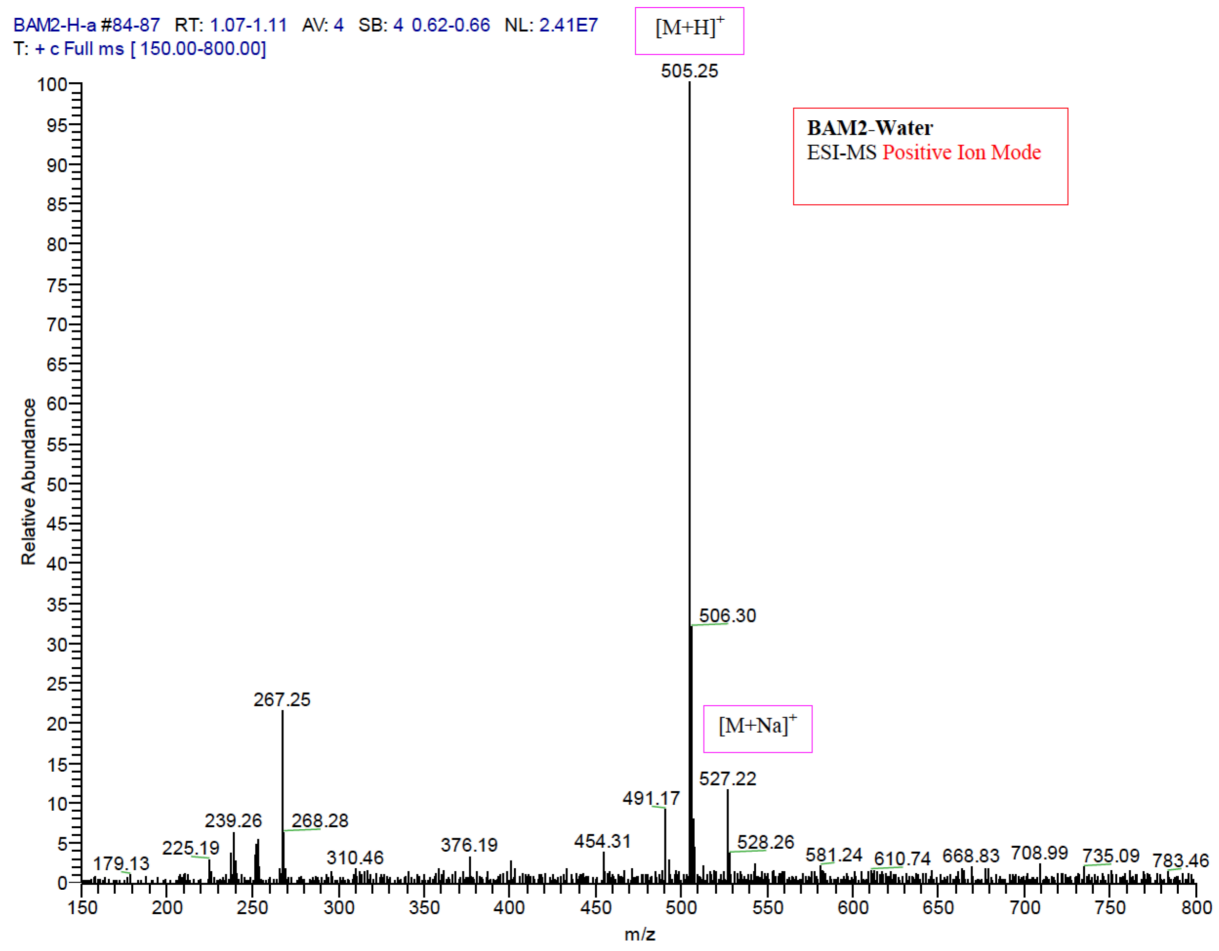

ESI-MS BAM2-EG 6 after incubation for 24 hours in $3 \mathrm{mM} \mathrm{H}_{2} \mathrm{O}_{2}$ :

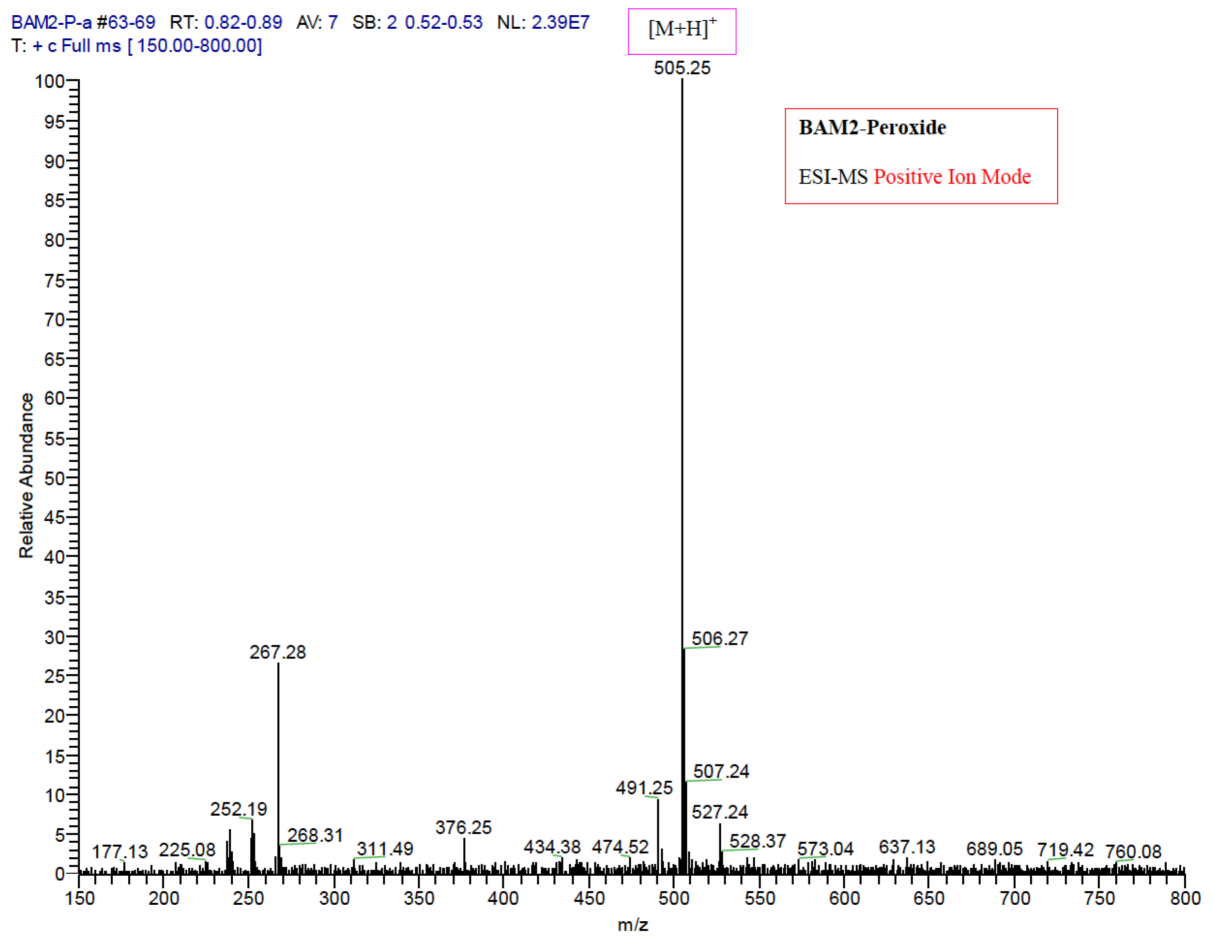




\section{ESI-MS BAM3-EG 6 in Water:}

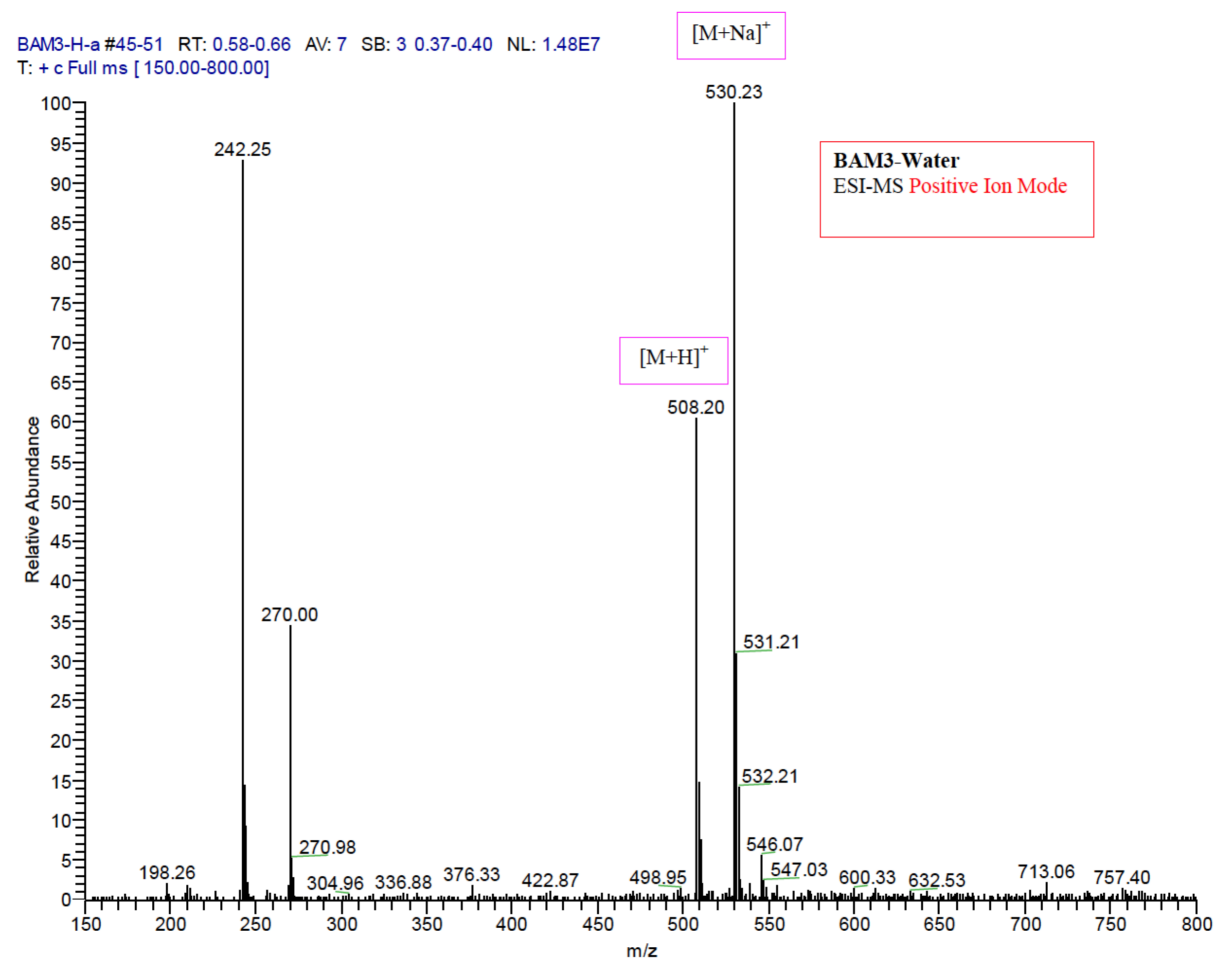

ESI-MS BAM3-EG 6 after incubation for 24 hours in $3 \mathrm{mM} \mathrm{H}_{2} \mathrm{O}_{2}$ :

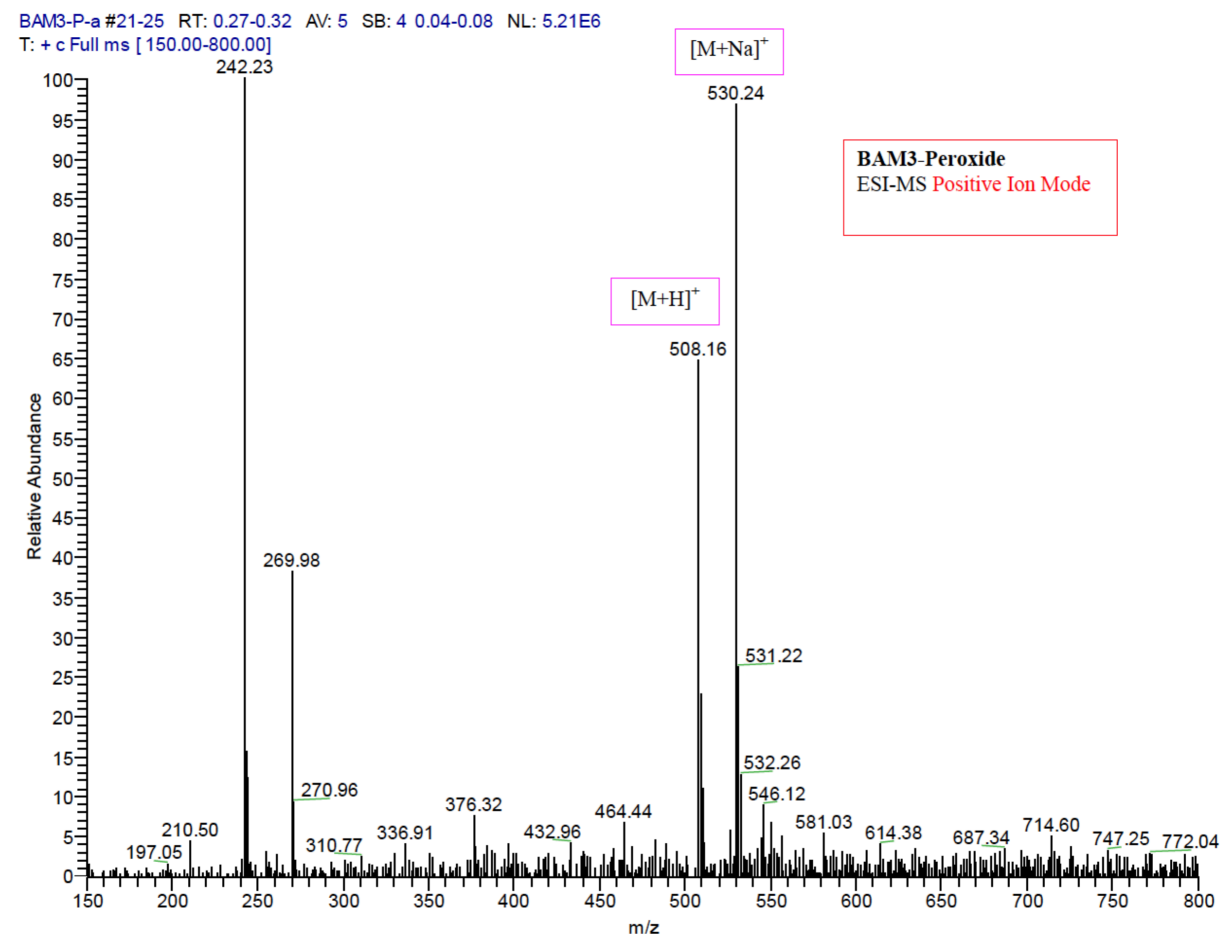


Additional Data for Catalase-Aß Co-localization Study.

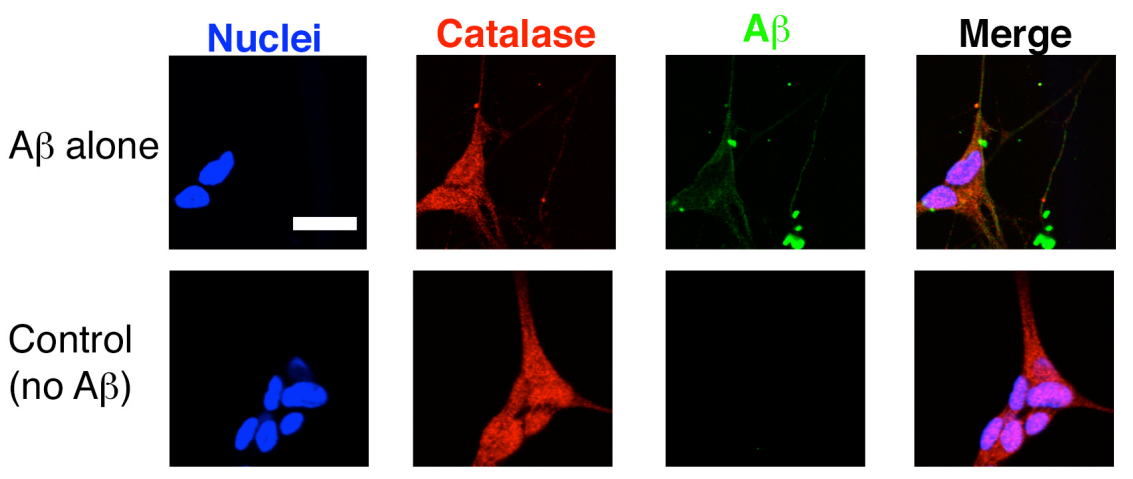

Figure S7: Co-localization of aggregated A $\beta$ (1-42) with catalase in SH-SY5Y cells. Fluorescence micrographs of representative z-slices within a cell illustrate the co-localization of catalase (red) and $A \beta$ peptides (green) Negative control is shown where no $A \beta$ was added to the cells. Scale bar $=20 \mu \mathrm{m}$.

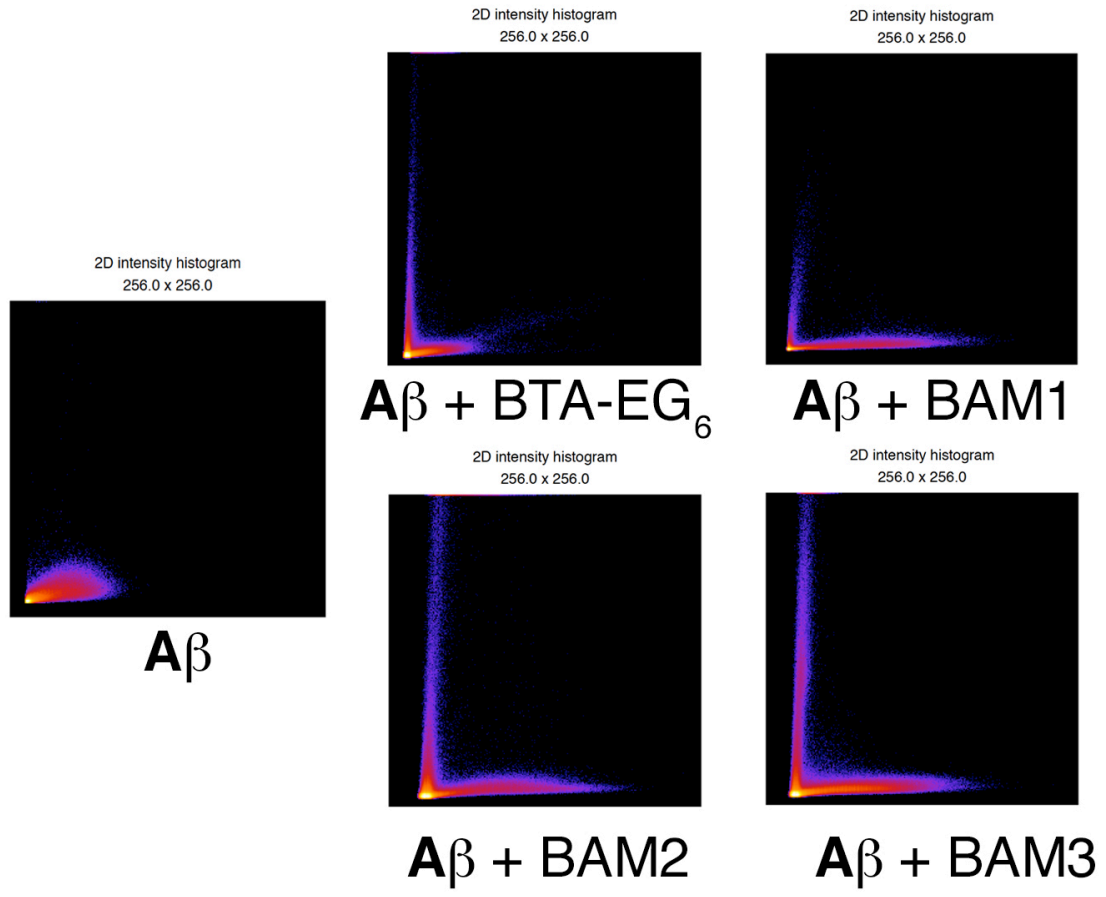

Figure S8: Corresponding 2-D histogram scatter plots generated from images in Figure 4 representing the colocalization of Catalase (channel 1) and $A \beta$ (1-42) (channel 2) for cells treated with either $\mathrm{A} \beta$ alone or $\mathrm{A} \beta$ plus compound. Increasing $\mathrm{X} / \mathrm{Y}$ correlation in these histograms indicates increased colocalization of $\mathrm{A} \beta$ and catalase. The histograms were generated from Image $\mathrm{J}$. 


\section{Supporting Information References:}

(1) Cifelli, J. L., Dozier, L., Chung, T., Patrick, G. N., and Yang, J. (2016) Benzothiazole Amphiphiles Promote the Formation of Dendritic Spines in Primary Hippocampal Neurons. $J$. Biol. Chem. published online March 28, 2016. DOI: 10.1074/jbc.M115.701482.

(2) Ranu, B. C., and Jana, R. (2006) Ionic Liquid as Catalyst and Reaction Medium - A Simple, Efficient and Green Procedure for Knoevenagel Condensation of Aliphatic and Aromatic Carbonyl Compounds Using a Task-Specific Basic Ionic Liquid. European J. Org. Chem. 2006, 3767-3770.

(3) Namboodiri, V. V., and Varma, R. S. (2002) Solvent-Free Sonochemical Preparation of Ionic Liquids. Org. Lett. 4, 3161-3163.

(4) Prangkio, P., Rao, D. K., Lance, K. D., Rubinshtein, M., Yang, J., and Mayer, M. (2011) Self-assembled, cation-selective ion channels from an oligo(ethylene glycol) derivative of benzothiazole aniline. Biochim. Biophys. Acta 1808, 2877-85.

(5) Park, N., Heo, Y., Kumar, M. R., Kim, Y., Song, K. H., and Lee, S. (2012) Synthesis of Benzothiazoles through Copper-Catalyzed One-Pot Three-Component Reactions with Use of Sodium Hydrosulfide as a Sulfur Surrogate. European J. Org. Chem. 2012, 1984-1993.

(6) Zhao, X., and Yang, J. (2010) Amyloid- $\beta$ peptide is a substrate of the human $20 \mathrm{~S}$ proteasome. ACS Chem. Neurosci. 1, 655-660. 